\title{
Effect of Structural Funds on Housing Market Sustainability Development-Correlation, Regression and Wavelet Coherence Analysis
}

\author{
Łukasz Mach ${ }^{1}\left(\mathbb{D}\right.$, Karina Bedrunka ${ }^{2}$, Anna Kuczuk ${ }^{3, * \mathbb{D}}$ and Marzena Szewczuk-Stępień ${ }^{4}$ (D) \\ 1 Department of Economics, Finance, Regional and International Research, Opole University of Technology, \\ Luboszycka 76, 45-036 Opole, Poland; 1.mach@po.edu.pl \\ 2 Marshal's Office of the Opolskie Voivodeship, Piastowska 14, 45-082 Opole, Poland; karbed74@gmail.com \\ 3 Department of Thermal Engineering and Industrial Facilities, Opole University of Technology, \\ Prószkowska 76, 45-758 Opole, Poland \\ 4 Department of Regional Policy and Labour Market, Opole University of Technology, Luboszycka 76, \\ 45-036 Opole, Poland; m.szewczuk-stepien@po.edu.pl \\ * Correspondence: a.kuczuk@po.edu.pl
}

Citation: Mach, Łukasz, Karina Bedrunka, Anna Kuczuk, and Marzena Szewczuk-Stępień. 2021 Effect of Structural Funds on Housing Market Sustainability DevelopmentCorrelation, Regression and Wavelet Coherence Analysis. Risks 9: 182. https://doi.org/10.3390/risks9100182

Academic Editor: Mogens Steffensen

Received: 25 August 2021

Accepted: 9 October 2021

Published: 15 October 2021

Publisher's Note: MDPI stays neutra with regard to jurisdictional claims in published maps and institutional affiliations.

Copyright: (c) 2021 by the authors. Licensee MDPI, Basel, Switzerland. This article is an open access article distributed under the terms and conditions of the Creative Commons Attribution (CC BY) license (https:/ / creativecommons.org/licenses/by/ $4.0 /)$
Abstract: Effective acquisition of funds, including European Union (EU) funds, designated for example, creating economic and social processes, may have a real impact on the elimination of the negative outcomes of the current position of the EU on the global scale. The aim of the research is to indicate the impact of spending funds from the Regional Operational Program of the Opolskie Voivodeship 2014-2020 (ROP OV) on a key macroeconomic area of the economy, i.e., the housing development sector in the region. The practical aim is to formulate recommendations and solutions that can offer guidelines for more effective spending of EU funds and their effect on the macroeconomic dimensions of the economy. The article proposes an innovative approach to linking EU payments in the region with the real estate market. The results of the research and the analyses made on this basis showed a positive impact of the payments made from the ROP OV on selected macroeconomic indicators, i.e., the number of permits issued for the construction of new apartments and the number of currently implemented housing investments. The obtained results should be used in the decision-making process at the level of regional and national authorities responsible for the payment of EU funds. In this article, prior to the research process, a literature review was made. It covered various aspects of the evolution and development of research in the area of regional development. The research process was based on innovative methods of time variability analysis, correlation between the investigated determinants and coherence analysis for the studied dimensions. Data on payments from the ROP OV concern the years 2015-2020.

Keywords: regional development; EU resources; housing development market; sustainable development

\section{Introduction}

We are facing the deterioration of the position of the EU as the dominant world economy (Radulescu et al. 2018) as well as socio-economic situations in it due to the demographic situation on the global scale (Chłon-Domińczak et al. 2014). The study reported by Iuga and Mihalciuc (2020) clearly demonstrates the impact of specific macroeconomic indicators on economic growth. There are also other studies in this area, such as one by Bedrunka and Malik (2012), which emphasize that the EU encourages the application of a new approach to programming activities, the primary goal of which is to strengthen its competitiveness. The new paradigm of strategic development management in the EU forms a key element in building the competitive advantage of Europe and its regions. The approach to contemporary development policy aimed at increasing the EU's global position requires the implementation of multi-faceted, comprehensive, and simultaneous actions aimed at reviving lost population potential and counteracting further adverse changes. It 
is necessary for the concentration of intervention to adequately include diagnosis for areas of development that will result in the macroeconomic development of the EU as a whole, its individual member states and regions.

The regional policy of the EU involves the development of the potential for sustainable development in all regions of the community in that it should contribute to a high level of social, economic and territorial cohesion. It focuses on innovation depending on the economic structure, types of resources and income levels (Foray et al. 2018). This requires a locally tailored approach that is based on local opportunities and promotes innovative ideas through the interaction of local and general knowledge and endogenous and exogenous actors in the design and implementation of public policies (Barca et al. 2012).

We can also note that the development of the entire country is determined by the development of its individual regions, the growth potential of which has been and is stimulated as a result of the support of EU funds for its regions. In Poland, this support has taken place since 1999, and to much greater degree in 2004, i.e., after Poland's accession to the EU. At present, the third perspective of spending EU funds is about to end, i.e., the years 2014-2020, and it was preceded by the budgets for years 2004-2006 and 2007-2013. Since the beginning of this period, Poland has been the largest recipient of structural funds in the EU. In the current perspective, the total sum is over EUR 77 billion. One of the leading regions in terms of the rate of spending EU funds is the Opolskie Voivodeship, where at the same time activities and priorities in the Regional Operational Program of the Opolskie Voivodeship for 2014-2020 (ROP OV) are aimed at improving the economic and social situations, including the demographic one.

Taking into account the above, that is, the need to implement a new paradigm of strategic management, whose outcome should be perceived through an increase of the region's competitiveness, the aim of the research was to indicate the impact of spending funds from ROP OV on the key macroeconomic area of management, i.e., the regional housing construction market. The conducted research and analyses made it possible to indicate positive relations between the development of the regional housing market, i.e., the number of permits issued for the construction of new apartments and the number of currently implemented housing investments, and the spending of EU funds in the Opolskie Voivodeship. The article proposes an innovative approach to linking EU payments in the region with the real estate market. In this article, prior to the research process, a literature review was made on the issue, which covered various aspects of the evolution and development of research in the area of regional development. The research process was based on modern methods of time variability analysis, correlation between the examined determinants and coherence analysis for the examined dimensions.

The research covers the period from 2015 to 2020, i.e., the current programming period of the EU. For those years, the voivodeship that is the smallest in terms of population, received EUR 914 million under ROP OV. This amount is the largest for the region since 1999. The funds were spent from 2015. In 2014, there were no payments from the ROP OV.

The information at the authors' disposal does not include data on the implementation of EU financial instruments for reconstruction after the COVID-19 pandemic, i.e., REACT EU. These instruments had not yet been implemented during the analytical period discussed in this article. The authors examined the economic impact of the pandemic, in particular health care, in other studies complementing this topic (Bedrunka et al. 2021).

\section{Literature Review}

2.1. Evolution and Concepts Applied in Research: Development, Region, Regional Development, Sustainable Development, Smart Development, including Smart Specializations

Poland's accession to the structures of the EU initiated and promoted scientific discussion concerned with development, regions, regional development, sustainable and smart development and methods of assessing these aspects. Many publications have been compiled on Polish and European grounds that deal with these issues directly or indirectly. The following theoretical analysis of the issue was carried out in accordance with Figure 1, which contains a diagram of the evolution and development of research in the area of regional development. 


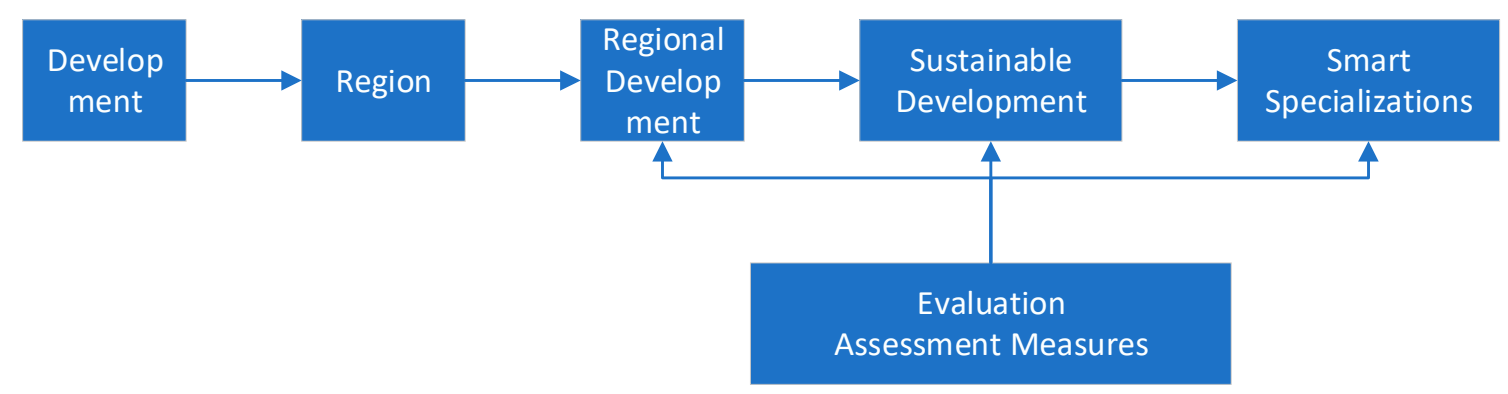

Figure 1. Diagram of evolution and development of research in the area of development, region, region's development, sustainable development, smart specializations evaluation, evaluation measures. Source: Authors' own work.

The study by Czaja (1992) contains an assumption that any change in economic, social and ecological systems should be understood under the notion of development, whereas the attribute of such a defined change is its irreversibility. Sztando (1998) states that the concept of development refers to the desired, positive quantitative, qualitative as well as structural transformations of a given system. Thus, space-time irreversibility does not form a single attribute of the development. It is worth adding another property to it, i.e., a positive assessment of the changes taking place from the point of view of a specific system.

According to Chądzyński et al. (2012), in the context of socio-economic development, a region should be considered in terms of the relations between development occurring on the local and global scales. The study by Di Mauro et al. (2010) indicates that in the world economy, which is dominated by the globalization process, a region can become competitive only when it can utilize its specific characteristics, combined with its ability to adapt to the conditions and requirements of the global environment. Currently, the notion of a region is classified mainly by the economic aspect, within which it is possible to list coherent areas due to the role of a specific branch of services or industry (Bedrunka and Dymek 2016). When an analysis is performed with regard to what is happening in it, studies most often determine whether a region is developing or not. Stawasz (2004) identifies a region as an element of development policy in terms of its economic, institutional, demographic, natural, infrastructural, spatial potential and living conditions. On the other hand, Klasik (2006) believes that in the economic aspect, the region can be considered in relation to the operation and interaction of the private sector and the public sector. On the other hand, taking into account the logic of the market economy operation, regions considered as public sector entities function in a multi-faceted system. In this aspect, mainly the national and supranational level is important, since regions that receive financial support from central authorities and supranational institutions, and where high-level institutions and infrastructure are located, have a chance to strengthen their competitiveness.

In this context, it is necessary to move on to the concept of regional development. According to Klasik (2006, p. 34), it is more and more often defined as a holistic, structural and strategic process within which the region's resources and conditions, its technological and cultural potential, and opportunities identified in regional, national and global markets are successfully applied by enterprises. The study by Mayer-Stamer (2016) emphasizes that the regional development is influenced by both internal (endogenous) and external (exogenous) factors. At the same time, models of regional development, which define a comprehensive, coherent way of explaining the mechanism of regional development, identify only the key (priority) potentials that are important for development. They mainly focus on the economic growth. The study by Szlachta (1996, p. 16) defines regional development as a systematic improvement of the competitiveness of businesses and the standard of living of the inhabitants, as well as an increase in the economic potential of regions, contributing to the socio-economic development of the country On the other hand, Kudłacz (1999) understands regional development as a permanent increase in the standard of living of the inhabitants and the economic potential within a specific unit of territorial classification. The definitions of Szlachta (1996) and Kudłacz (1999) can be 
considered very synthetic. The OECD defines regional development as a general effort to reduce regional disparities by supporting (employment-oriented and wealth-generating) economic activities in particular regions (OECD n.d.).

When a reference is made to the concept of regional development, it is worth noting that they are not always consistent due to the changing environment and thus they are subject to constant modifications. Sustainable development is one of the concepts of regional development. The study by Borys (2001) describes it as a process of changes in the states of dynamic equilibrium between local economic, social and ecological and spatial development. The ultimate goal of this process is to improve the broadly understood quality of life-and secure sustainability of natural resources. Development policy objectives formulated by public authorities are characterized by certain principles that make it possible to operationalize them (Malik 2011). The developmental paradigm of sustainable development in the regional policy of development involves a number of conceptual characteristics and principles of operation. These include the promotion of development, its stability and sustainability (Borys 2005, p. 75). Sustainable development defined as the concept of development policy determines the process of variations occurring throughout the states of a dynamic equilibrium between regional social, economic and environmental and spatial development aspects. According to Barbier et al. (1990), there are two integrated pillars of this concept, i.e., balance between aspects of order: social one (including political), economic and environmental one and the one taking into account sustainability of capital achieved through the creation and dissemination of innovation. Capitals are identified by various authors, including Biela (2001) who defines, e.g., human capital, and a similar approach is proposed by Tomer (1987) in the description of social and institutional capital, whereas El Serafy (1991) focuses interest on material and natural (ecological) capital.

Sustainable development should be analyzed very broadly, also in terms of the companies' performance in the global economy. Currently, research is often conducted in the field of sustainable production, and reports in this area include a study by Bedrunka (2020). Barska et al. (2020) evaluate the progress in the implementation of the concept of sustainable development in the social aspect of the EU in the years 2014-2018, with a particular emphasis on Poland. Širá et al. (2020) put forward the thesis that the increased emphasis on the factors of the knowledge-based economy increases the country's competitiveness, which contributes to its sustainable development.

The study by Antonescu (2014) identifies regional development that promotes the sustainable development of the EU and similarly, in all member states, and it is considered that it plays the role of an integral factor of the economic and social policy of the state. This approach emphasizes the growth model proposed in the Europe 2020 strategy (European Commission 2010b), which is based on three priorities: smart growth, sustainable growth and inclusive growth.

Smart development means the roles of knowledge and innovation are increasing as they act as driving forces for future development. This requires improving the quality of education, improving the effectiveness of research activities, fostering the transfer of innovation and knowledge in the EU, full exploitation of information and communication technologies and ensuring that innovative ideas turn into new products and services that contribute to increased growth, creating new jobs and solving social problems in Europe and the world. Elements such as entrepreneurship, financial resources and consideration of local needs and market opportunities are also necessary (European Commission 2010b). Mazur-Wierzbicka (2015) gives an outline of inclusive development that was broadly described in the Europe 2020 strategy in terms of taking actions aimed at supporting the economy with the purpose of ensuring high levels of employment, which will ensure social and territorial cohesion. In turn, it is already implemented through the program for new skills and employment and the European program for combating poverty. It is worth paying attention to the research conducted by Lafuente et al. (2020), which demonstrates 
the outcomes of the implementation of the Europe 2020 strategy from the point of view of the goals of poverty and social exclusion.

Zalewska and Świetlikowski (2017) identify smart growth in EC documents in terms of improving performance in the areas of: education (encouraging to learning, study and improving qualifications); research/innovation (creation of new products and services that would increase economic growth and employment and would help to solve social problems) and digital society, i.e., the use of information and communication technologies.

According to Foray et al. (2011), smart growth emerged in the context of the political concept of building smart specialization in regions, which was then introduced despite only limited theoretical framework. A clear path to building the Smart Specialization Strategy is presented in the EC document as: searching for market niches, increasing efforts to acquire knowledge aimed at economic activities that can potentially offer quick results on global markets, but also cope with social challenges such as globalization (European Commission 2010a). The study by Nowakowska (Nowakowska 2015) indicates clearly that an important pillar for building an innovative EU economy as part of smart development is related to the identification and development of smart specializations, both at the level of regions and countries. Smart specialization forms a new concept of creating economic specializations and at the same time serves as a tool for strengthening the position of regions in the global economy of knowledge and innovation. It is believed that the creators of this approach are members of the Knowledge for Growth (K4G) international expert group, especially its two leaders, Bart van Ark and Dominique Foray. Foray and Goenaga (2013) indicate that smart specializations focus on a more vertical and non-neutral intervention logic, i.e., on the process of identifying and selecting areas of intervention, implying the selection of technologies, domains and subsystems that could be favored within the regional policy. In their research, Dziedzic et al. (2015) indicate that smart and sustainable development form issues that are closely interrelated. The process of achieving smart specializations, including the regional innovation strategy, for example in the Podkarpackie Voivodeship, took on a character of a completely entrepreneurial discovery process. Basically, it covered two years: 2012 and 2013, although a number of documents and research results were included in it. The methodology of creating the regional innovation strategy, as well as the methodology used to assess all stakeholders, as well as the criteria for selecting smart specializations, were uniform in nature, showed continuity and consistency of individual stages. When creating the document, the methods were triangulated, so the final result is not a derivative of only one method used, but it was adopted when all the methods used provided the same or similar results. The basic methods utilized in the process of developing the strategy include: analysis of strategic documents and other available sources of knowledge, analysis of foresight projects carried out for the region's needs, SWOT analysis divided into socio-economic potential of the Podkarpackie Voivodeship, stakeholder analysis, also performed in order to select the most important stakeholders, various forms of meetings and discussions, practiced on a continuous basis, and analysis of the potential and possibilities of cluster development, performing primary research with a very wide economic spectrum.

The team headed by Malik developed an original model of selecting smart regional specializations and creating a regional innovation strategy by 2020 in the Opolskie Voivodeship and smart specializations based on the following methods and tools: content analysis, industry analyses, research on existing sources, time series/trend forecasting, expert, stakeholder consultation, Delphi method, creative imaging, impact assessment, PEST analysis (political, economic, socio-cultural, technological), logic diagram, environmental scanning, vision creation and future workshops. They were linked and used in the design of the specific stages of the strategy (Bedrunka 2015; Zarząd Województwa Opolskiego 2014). At the same time, these researchers broadly describe the process of its monitoring based on the action plan and selected indicators, which is to a lesser extent visible in the works carried out for the Podkarpackie Voivodeship. 
Another interesting example of research in this area is the analysis of higher education institutions by Kangas and Aarrevaara (2020) from the point of view of their role as innovation brokers in the context of smart specialization. Ponsiglione et al. (2018) performed an analysis of the entire regional innovation system, in the context of the delays of the European regions.

\subsection{Real Estate Market and Its Impact on the Economy}

The real estate market is one of the most important markets from the point of view of maintaining macroeconomic stability. Its parameters are directly reflected in the investment activities of the supply and demand sides of entities operating on it. If this market is characterized by stable economic parameters and parameters proving its development, then its dynamic development should be expected. However, in the event of its stagnation or recession, the volume of investment shrinks (Zhang et al. 2018). Interesting studies on macroeconomic stability in connection with the state of the real estate market can be found in Dell'Ariccia et al. (2021), where the impact of economic crises on the state of the real estate market is analyzed in detail. The condition and parameters of the real estate market are particularly important from the point of view of the economic situation that took place and is taking place during the COVID-19 pandemic (Mach 2021), and in particular the cost calculation (Batrancea et al. 2019). Comprehensive studies showing the negative impact of the COVID-19 pandemic on the real estate market, in particular the residential, commercial and mortgage markets, are presented in Balemi et al. (2021). JLL Research \& Strategy report emphasizes that countries all over the world tried to introduce changes to the real estate policy in order to limit the negative effects. They introduced changes in the property policy aimed largely at reducing the burden on tenants, such as preventing evictions, reducing rents (JLL Research \& Strategy 2020). De Toro et al. (2021) showed that there was a decrease in transactions on the residential market by over $15 \%$ in Naples in the first quarter of 2020 compared to the corresponding period of 2019. This change was a derivative of the economic instability of households, lower incomes, limited activity of real estate agencies or the tourism sector. Furthermore, Croom et al. (2020) emphasize the importance of COVID-19's impact on areas of society, and more specifically on the commercial real estate market. Their analyses showed the visible impact of COVID-19 on the commercial real estate market. However, the final impact of COVID-19 on the commercial real estate market is still being analyzed.

However, the Polish real estate market, both domestically and regionally, is characterized by good parameters during the pandemic. In this market, there is a continuous increase in the potential of the supply side (e.g., through an increase in the number of flats whose construction has been completed) and the demand side (e.g., due to the growing volume of sold flats). The described situation is influenced, among others, by historically low interest rates, a narrow range of investment opportunities and the belief that real estate investments are safe from the point of view of maintaining or growing the investment capital held (Augustyniak et al. 2011).

\subsection{ROP Payments and Their Impact on the Economy}

The economy of a country or a region is influenced by many macroeconomic factors, which change over time, and their intensity also changes (Schmidhuber and Qiao 2020). The Polish economy, including the Opolskie Voivodeship, has been benefiting from EU funds under the European Cohesion Policy for over 20 years. Especially the last two programming periods in the European Union, i.e., the years 2007-2013 and 2014-2020, are very important. At that time, Poland was the largest recipient of European funds among 27 member states. This money supports all spheres of the economy. They are aimed at strengthening research and development activities, digitization of private and public entities, climate protection, development of human resources from the perspective of the needs of the labor market, as well as community integration and inclusion (Bedrunka and Malik 2014). The period of the COVID-19 pandemic has clearly shown that European funds 
are a very important instrument for also supporting health protection (Bedrunka et al. 2021; Boin et al. 2020). The civilization advancement that took place in Poland, including the Opolskie Voivodeship, in such a short time should be clearly identified as a success of the European Union's cohesion policy. It provided the opportunity to significantly increase and better target many investments, as well as to launch activities aimed at people who are in the labor market or who remain outside of it. A synthetic expression of the position of the member states and regions is the GDP per capita according to the purchasing power parity (European Commission 2021). Therefore, the authors recognize that the pace of EU fund disbursement under individual investments should be considered an important measure of the impact on the economy of the Opolskie Voivodeship. Other interesting research results describing the impact of EU funds on the elections of the mayor in Poland can be found in Banaszewska and Bischoff (2021). The study by Crescenzi et al. (2019) describes the local benefits of an EU payment. An analysis of these benefits, extended to include cohesion policy, can be found in the work of Cunico et al. (2021). Very interesting research from the point of view of econometric modeling of EU funds issues can also be found in the work of Cardenete and Delgado (2015).

\section{Analysis of the Effect of Operating Programs on Selected Determinants of Housing Market Development}

\subsection{Data and Methods}

When an analysis was performed with regard to the impact of payments made under the ROP OV on selected determinants of the development of the housing market, selected stages of the housing development process were investigated. First of all, the number of permits granted for new apartments was analyzed, whereas the number of currently completed housing investments was analyzed in the second stage. Each of the described areas was examined by following a scheme consisting of:

(a) Analysis of time variability of investigated determinants vs. payments made within the framework of the ROP OV. The functional analysis was performed by applying common multiple regression principles $\hat{y}_{t}=\hat{\alpha}_{0}+\hat{\alpha}_{1} x_{1}+\hat{\alpha}_{2} x_{2}$ according to the assumption that theoretical values of the variable $\hat{y}$ can be recorded in matrix form (cf. Equation (1)).

$$
\hat{y}=\hat{\alpha} X
$$

The estimation of structural parameters of the model using the classic method of least squares was performed with the use of an estimator expressed by Equation (2).

$$
\hat{\alpha}=\left(X^{T} X\right)^{-1} X^{T} y
$$

where:

$\hat{\alpha}$-Living Standards Measure (LSM) estimator of unknown parameter vector $\alpha$, $y$-column vector of observation on an explanatory variable of dimensions $(n \times 1)$, $X$-observation matrix on dimensional explanatory variables $(n \times(\mathrm{k}+1))$.

(b) Analysis of correlations between investigated determinants and payments incurred within the framework of the ROP OV. This analysis was performed using the Pearson linear correlation, assuming that $x$ and $y$ form the investigated random variables with discrete distributions. The terms $x_{i}$ and $y_{i}$ denote the values of random samples of these variables $(i=1,2, \ldots, n)$ and $(i=1,2, \ldots, n)$, while $\bar{x}$ and $\bar{y}$ represent the mean values of these samples. Consequently, the linear correlation coefficient estimator was determined on the basis of Equation (3).

$$
r_{x y}=\frac{\sum_{i=1}^{n}\left(x_{i}-\bar{x}\right)\left(y_{i}-\bar{y}\right)}{\sqrt{\sum_{i=1}^{n}\left(x_{i}-\bar{x}\right)^{2}} \sqrt{\sum_{i=1}^{n}\left(y_{i}-\bar{y}\right)^{2}}}
$$


(c) Coherence analysis for investigated dimensions. Wavelet coherence analysis constitutes a measure of the correlation between two signals in the time-frequency domain. Wavelet coherence finds application in the analysis of non-stationary signals and offers the means for identification of cycle synchronization. From the point of view of applied computational engineering, coherence was derived by application of the analytical Morlet wavelet. A useful tip that serves the purposes of the analysis of periodicity synchronization in the examined variables involves the possibility of investigating the directions of arrows representing phase distributions. The goal of wavelet coherence analysis first of all involves the determination of wavelet cross-spectrum, which forms a measure of the distribution of two signals. This spectrum of two time series takes the form given by Equation (4).

$$
C_{x y}(a, b)=S\left(C_{x}^{*}(a, b) C_{y}(a, b)\right)
$$

where $C_{x}(a, b) i C_{y}(a, b)$ denote the continuous wavelet significance of the values of variables $x$ and $y$ on the scale $a$ and with regard to position denoted by $b$. The superscript * forms a complex conjugate, whereas $S$ forms an operator applied for data smoothing in time and scale. Subsequently, wavelet coherence for two time series, $x$ and $y$, is derived by application of Equation (5).

$$
\frac{\left|S\left(C_{x}^{*}(a, b) C_{y}(a, b)\right)\right|^{2}}{S\left|C_{x}(a, b)\right|^{2} S\left|C_{y}(a, b)\right|^{2}}
$$

The data applied for the analyses was derived from the databases of the Central Statistical Office (BDL n.d.) and the Marshal's Office of the Opolskie Voivodeship. This data was gathered throughout the period from 2015 to 2020.

\subsection{Results and Discussion}

In Figures 2 and 3, we can observe the effect of increased ROP OV payments on the increase in the potential in terms of building permits granted and in terms of dwellings under construction in 2019. Taking into account the characteristics of the identified dependencies, it can be noted that the payments had an activating effect on the granted of building permits and on the number of dwellings whose construction began. From the presented graphs, we can also see that the payments formed an anticipatory phenomenon both for the variable construction permit granted and for the completed dwellings. Table 1 presents the basic statistics that allow for an initial characterization of the studied phenomena. It is worth noting that in the analyzed variables the mean values are close to the median values. This is crucial for the useful use of the calculated descriptive statistics in the analyses performed in this study.

Table 1. Descriptive statistics of analyses variable.

\begin{tabular}{cccccc}
\hline Analyzed Variable & Mean & Median & Std & Min & Max \\
\hline Permission granted & 250 & 243 & 89 & 103 & 547 \\
Construction started & 222.4 & 199 & 104 & 38 & 630 \\
ROP OV payment & 46.85 & 41.3934 & 42 & 0 & 269 \\
\hline
\end{tabular}

Source: Authors' own work. 

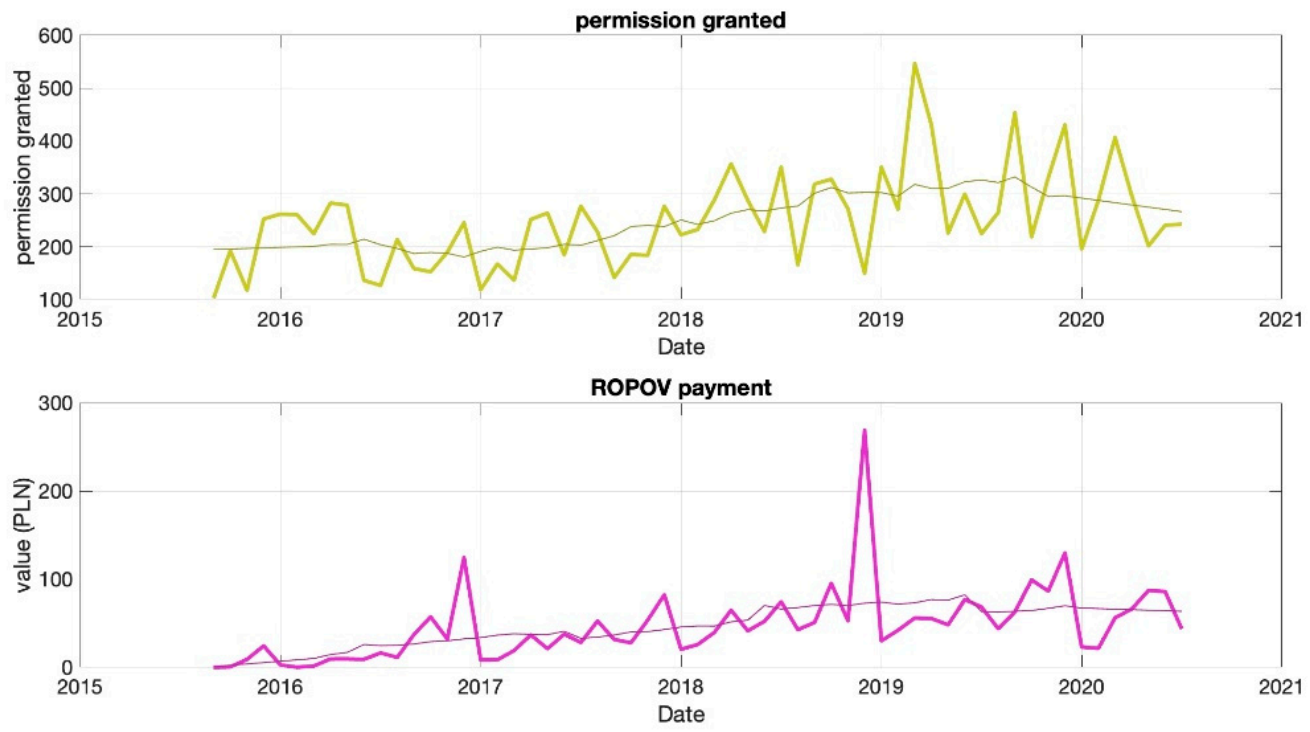

Figure 2. Waveform representing permission granted of dwellings and payments made within the framework of the ROP OV. Source: Authors' own work.
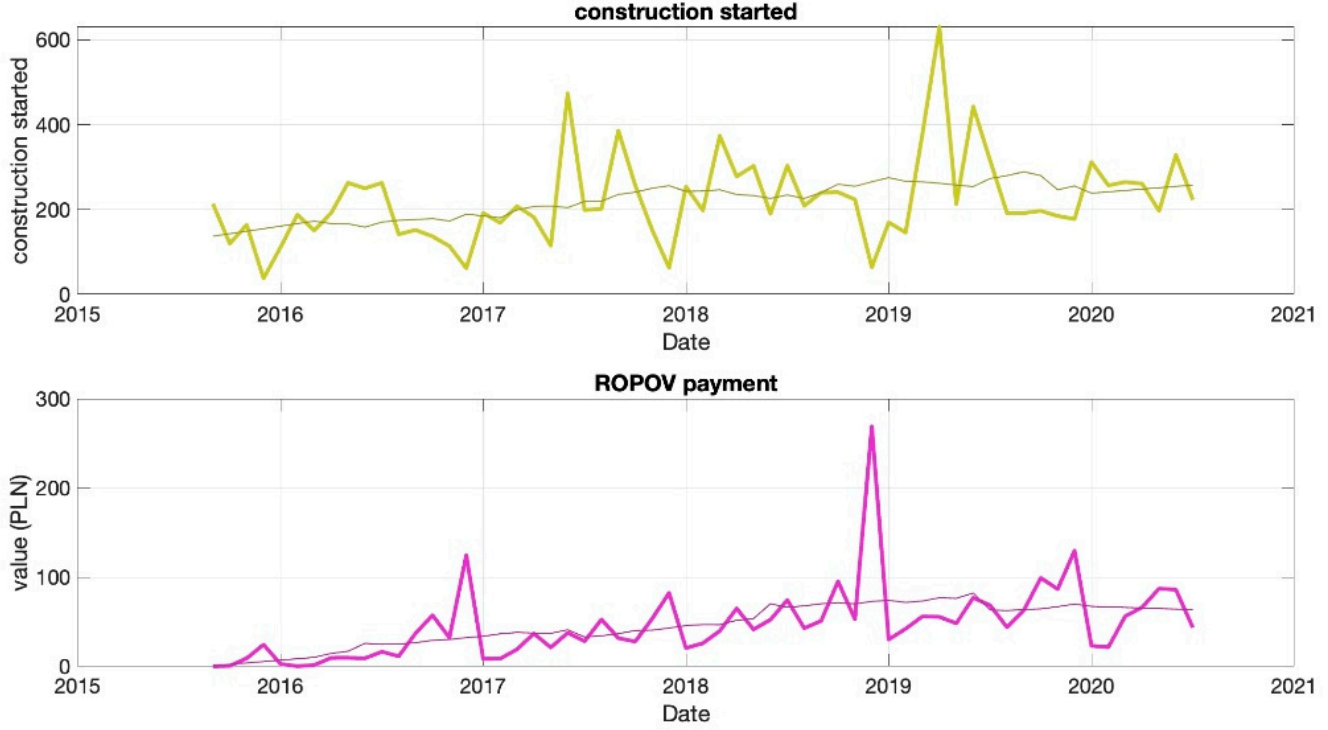

Figure 3. Waveform representing started construction of dwellings and payments made within the framework of the ROP OV. Source: Authors' own work.

When an attempt was made to quantify the investigated dependencies, the process of developing regression models was performed, whose structural form is presented in Figures 4 and 5, and it shows quantitative dependencies for granted permits (Figure 4) and started construction of dwellings (Figure 5), respectively, depending on the payments granted from the ROP OV. Taking into account the formal provisions of the constructed regression models, we can note that if we increase the payments under the ROP OV by PLN 1 million, leads to an average increase in the issued building permits by 1.29 , while in the case of dwellings under construction - an increase of 0.331 . The higher value of the parameter describing building permits proves the greater flexibility (sensitivity of changes to external factors) of this economic variable when we compare the data to the number of dwellings under construction (see Figures 4 and 5). 


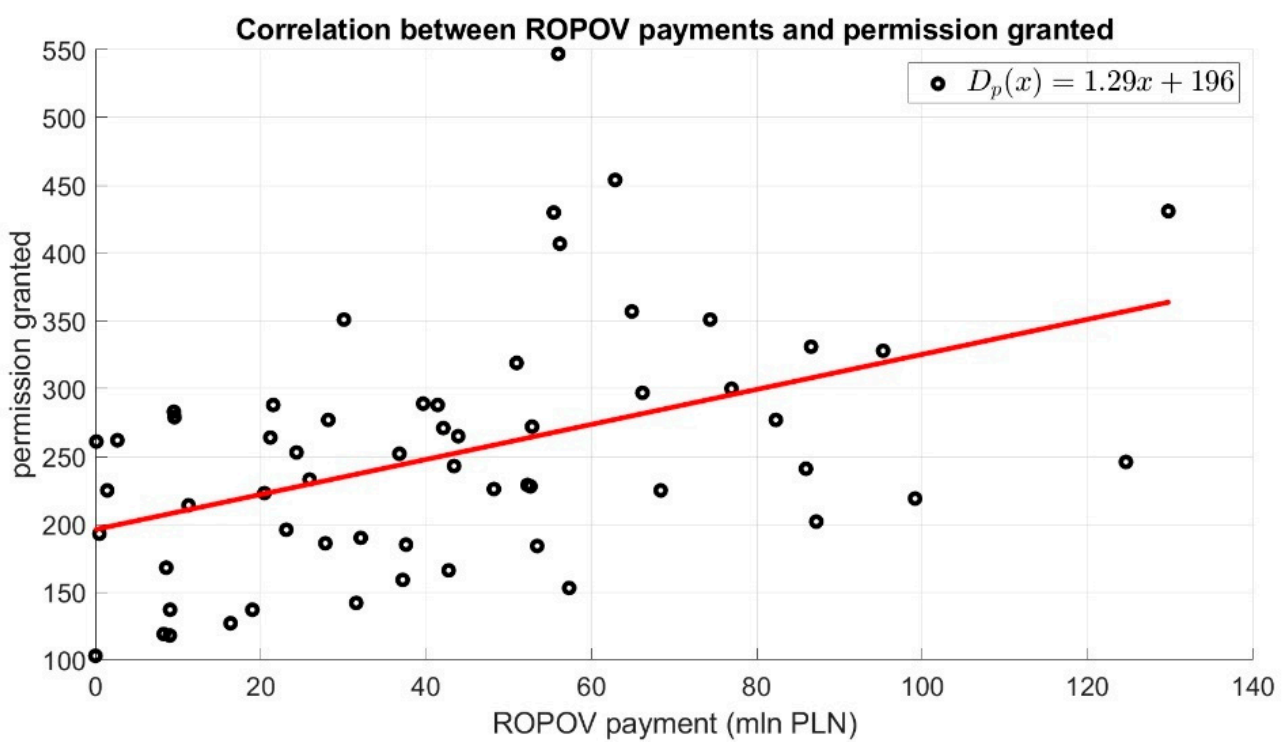

Figure 4. Correlation between total permissions granted and payments made in the ROP OV program. Source: Authors' own work.

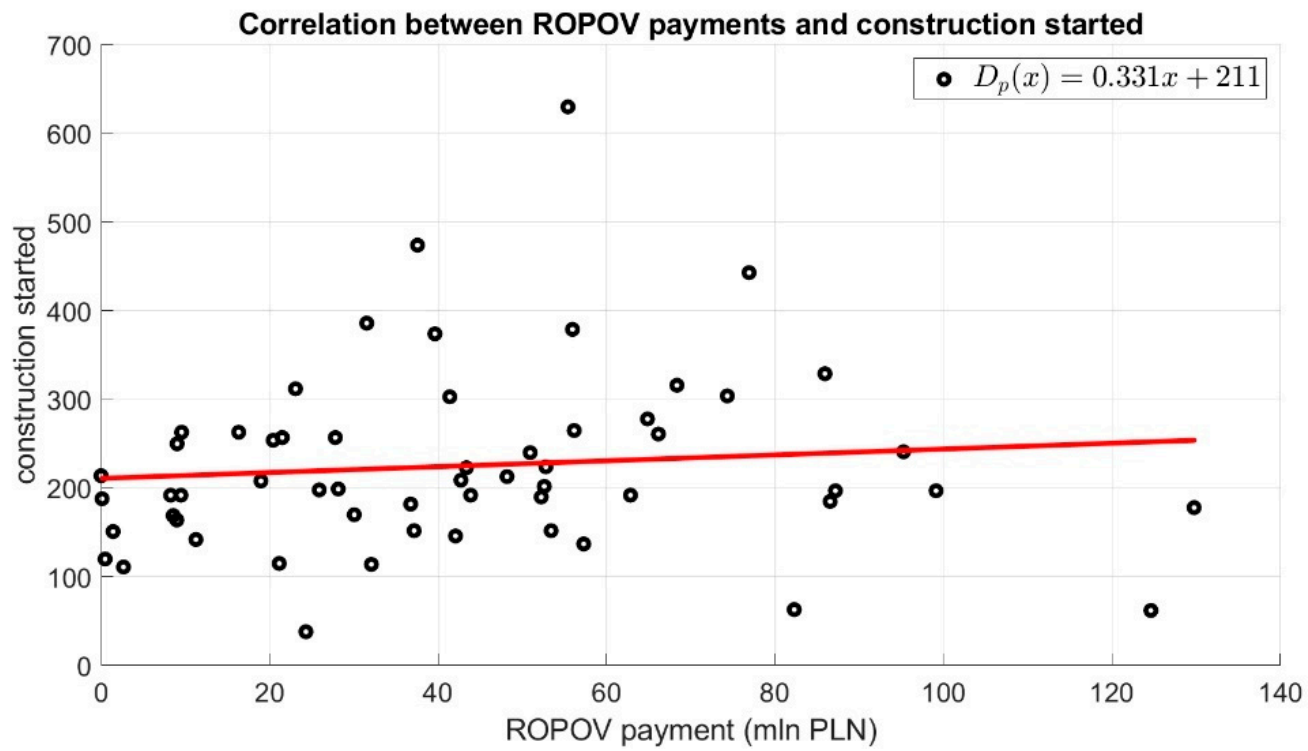

Figure 5. Correlation between dwelling construction started and payments made in the ROP OV program. Source: Authors' own work.

Tables 2 and 3 present the parameters of regression models developed on the basis of the studied correlations between the studied variables.

Table 2. Parameters of the regression model for the variables: building permits and the ROP OV payment.

\begin{tabular}{cccc}
\hline Estimate & SE & $\boldsymbol{t}$-Stat & $\boldsymbol{p}$-Value \\
\hline 196.17 & 18.25 & 10.75 & $3.15493 \times 10^{-15}$ \\
1.29 & 0.34 & 3.73 & 0.000441825 \\
\hline
\end{tabular}

Source: Authors' own work. 
Table 3. Regression model parameters for the following variables: construction started and the RPO OV payment.

\begin{tabular}{cccc}
\hline Estimate & SE & $t$-Stat & $p$-Value \\
\hline 210.93 & 27.28 & 9.06 & $1.44817 \times 10^{-12}$ \\
0.33 & 0.44 & 0,75 & 0.456307637 \\
\hline
\end{tabular}

Source: Authors' own work.

In the next stage of the research, an attempt was made to assess the significance of time delays between the analyzed diagnostic variables. When the process of assessing significant time delays between the examined variables was conducted, we noted that also in this case, the variable representing granted permissions is characterized by a greater flexibility of fluctuations compared to one that represents started construction of dwellings. A confirmation of this that there is a 3-month delay period compared to the realized ROP OV payments, compared to the 6-month delay period for apartments under construction (cf. Figures 6 and 7).

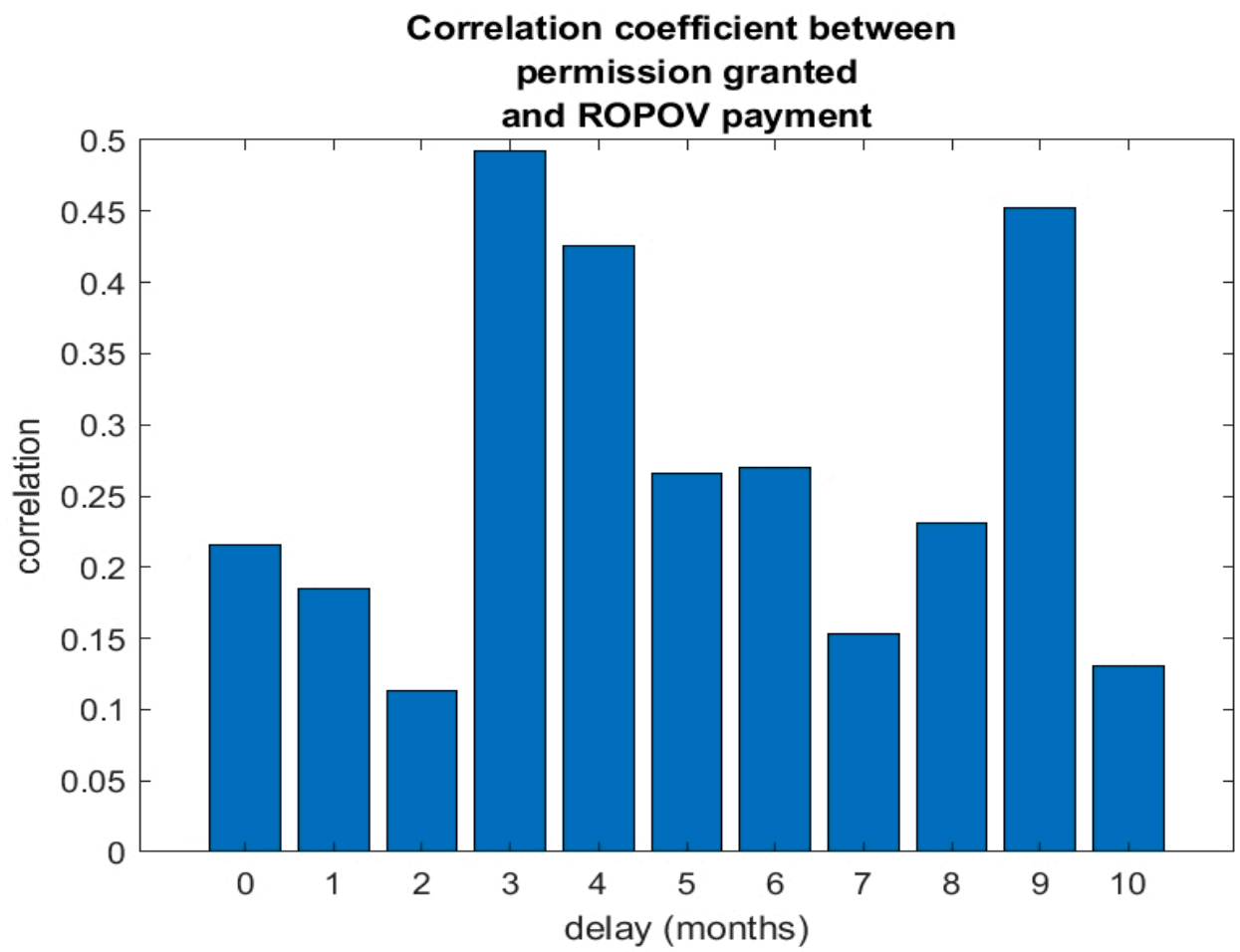

Figure 6. Correlation chart for granted permission and the RPO OV payments. Source: Authors' own work.

The last problem in the conducted research involved the assessment of the interdependence and synchronization of any periodicity. When the interdependence and synchronization of the cyclicality was examined, it was assumed that it would be tested for payments made under ROP OV and the number of granted permits (cf. Figure 8) and the number of completed dwelling investments (cf. Figure 9). In order to conduct the research taking into account the above assumption, an analysis of the wavelet coherence between the described relations was performed. In the diagram that contains wavelet coherence, the arrows show the estimates of wavelet phase angles ${ }^{1}$. 


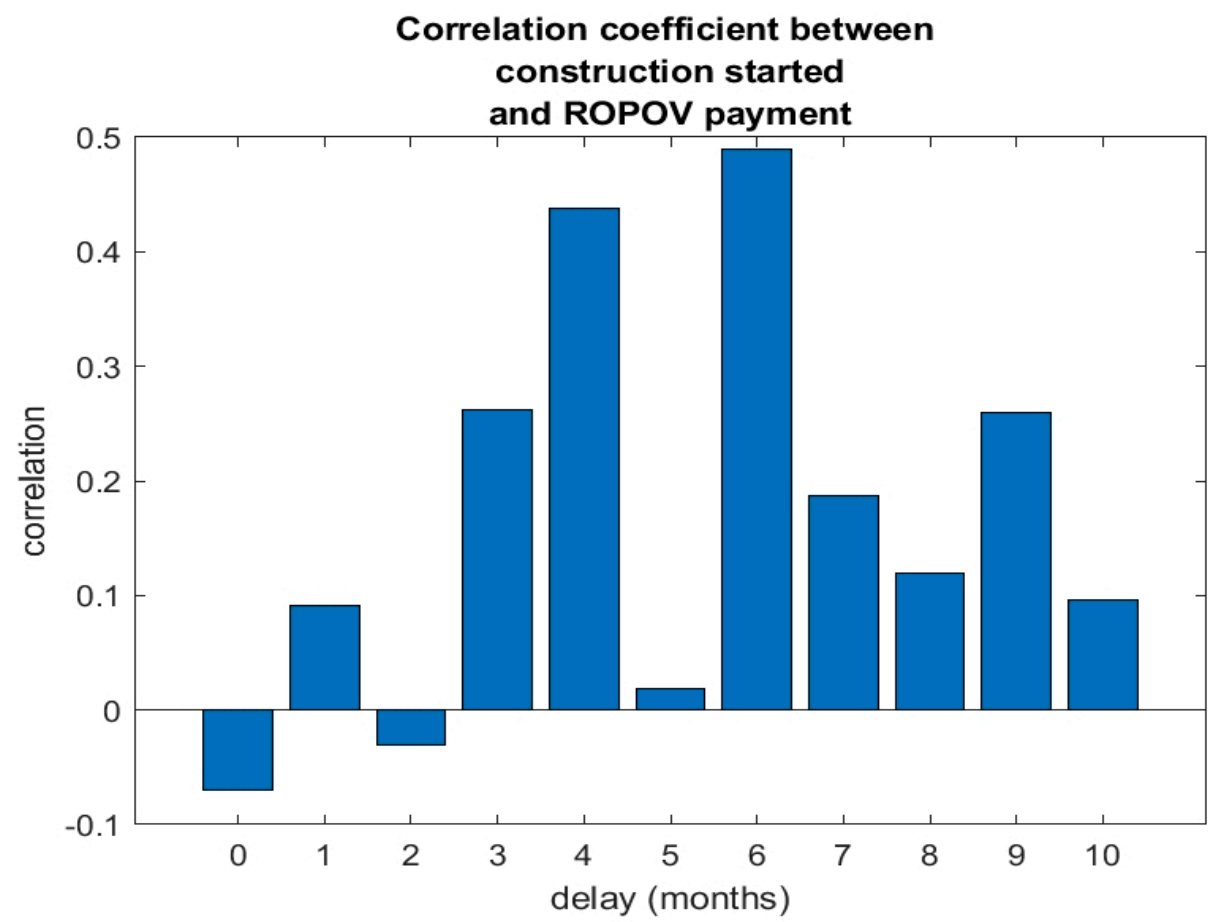

Figure 7. Correlation chart for variable: started construction of dwellings and the ROP OV payments. Source: Authors' own work.

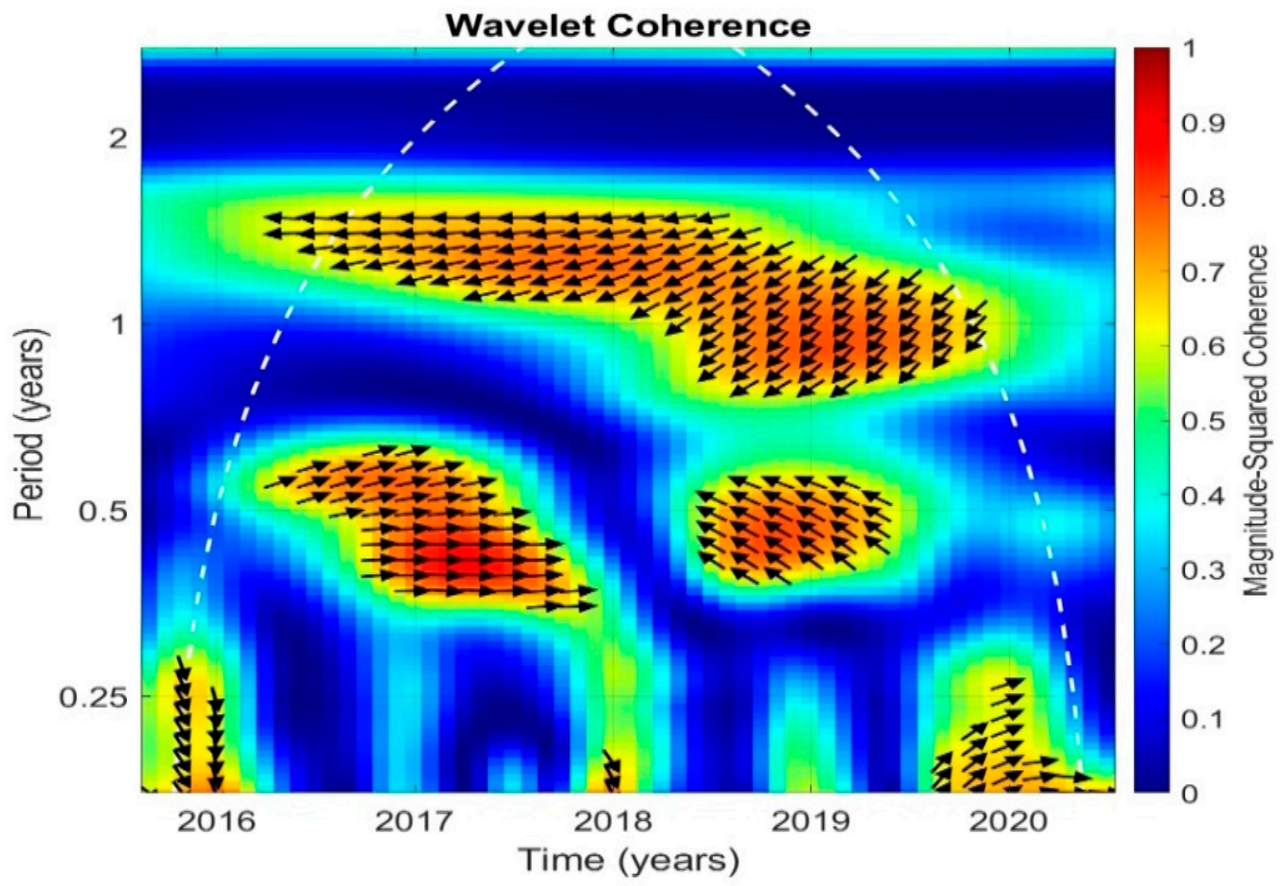

Figure 8. Wavelet coherence between granted permits and granted payments. Source: Authors' own work. 


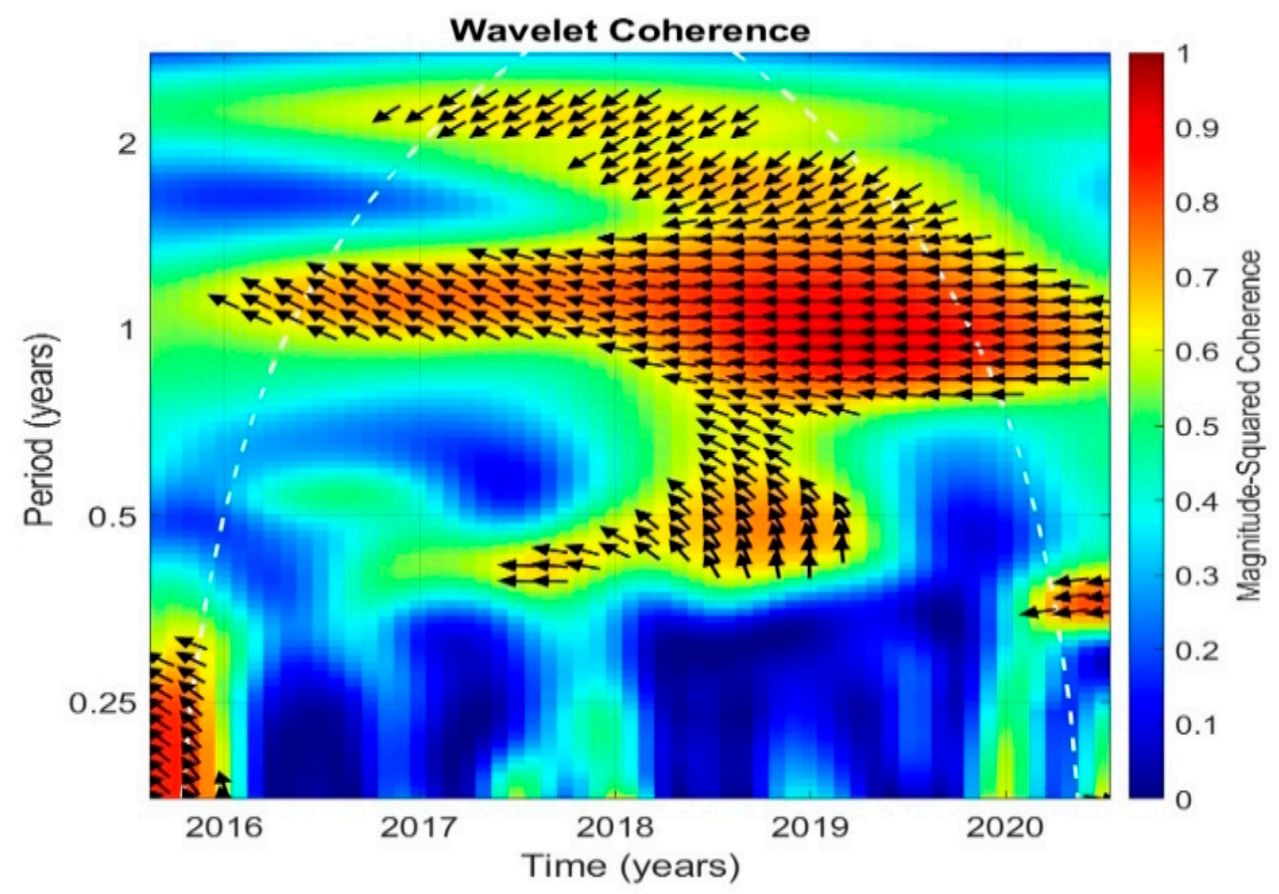

Figure 9. Wavelet coherence between construction started and made payments. Source: Authors' own work.

For the wavelet coherence in Figure 8, representing the relations between granted permits and payments under the ROP OV, a linear correlation can be noted for semi-annual cycles in the period from 2016 to 2018 and for the year 2019. We can also note that in the years 2016-2020 in the investigated example we have to do with a linear correlation for the annual and 18-month cycles.

Throughout the description of synchronization occurring when identifying cyclicality, we can note that:

- annual and 18-month-cycles occur in a counter-phase,

- semi-annual cycle occurs in-phase and forms a preceding cycle.

Another round of the analysis of the linear correlation of cyclicality was performed for building permits with payments granted under the ROP OV (Figure 9). From the analysis of the wavelet coherence, we can conclude that the annual cycle forms the dominant cyclical relation, which means that a delayed counter-phase cycle is formed. This cycle was recorded between 2016 and 2020. It should also be noted that in the period 2017-2019 there is a linear relationship between the semi-annual and biennial cycles.

\section{Conclusions}

\subsection{Conclusions of the Study}

The results of the study suggest the following conclusions:

1. In 2019, on the basis of Figures 2 and 3, we can note a noticeable impact of increased ROP OV payments on the increase in potential in the housing market. Thus, the payments under the ROP OV have had an activating effect on the total granted permits and on the construction started data.

2. In the quantitative analysis of the investigated relations, the process of building regression models was performed, the structural form of which is presented in Figures 4 and 5. The graphs illustrate the following relations: on average an increase of payments made under the ROP OV by PLN 1 million, leads to an increase in the granted permits by 1.29. In the case of dwellings under construction, we can note an increase of 0.331 . The higher value of the ratio of building permits demonstrates 
that this economic variable is more flexible (and sensitive to variations in the external factors) compared to the case of the number of dwellings under construction.

3. In the process of assessment of the significant time delays between the examined variables, granted building permits are characterized by a greater degree of variations in comparison to data for dwellings under construction. For building permits, there is a 3-month delay compared to the ROP OV payments, for apartments under construction the delay is 6 months (see Figures 6 and 7).

4. The final stage of the research involved the assessment of the correlation and synchronization of any periodicity. The study conducted an analysis of the wavelet coherence between the established relations. For the wavelet coherence shown in Figure 8, i.e., for data between granted permits and payments made, there is a linear correlation for the bi-annual cycle in 2016-2018 and in 2019. We can also note that in the years 2016-2020 there is a linear relationship between the annual and 18-month cycles in the analyzed example. When the synchronization for the identified cyclicity is described, it can be noted that: the annual cycle and the 18-month cycle occur in a counter-phase, and the bi-annual cycle forms a cycle that occurs in phase and represents a leading cycle.

5. From the analysis of the linear correlation of cyclicity and the analysis of the course of wavelet coherence performed for dwellings under construction (Figure 9), it can be concluded that the dominant cyclical relations can be established with regard to the annual cycle, which is a cycle delayed in counter-phase. This cycle occurred in 2016-2020. It should also be noted that in 2017-2019 there is a linear relationship between semi-annual and two-year cycle.

\subsection{Summary of Findings}

The conducted research demonstrated the positive impact of realized payments from the ROP OV on selected macroeconomic parameters. The results of the study can be used in the decision-making process at the level of regional and national authorities responsible for the distribution of EU funds. Referring to the practical purpose of the research, the recommendations for authorities at all levels of expediting EU funds are as follows:

- The determination of the principles for implementing the operational program should be the subject of discussions and meetings with program stakeholders. This approach guarantees greater efficiency in distributing funds.

- The evaluation of the pace of spending EU funds, i.e., payments from the operational program, should be monitored on an ongoing basis in order to to introduce corrective measures early. The applied correction actions should be based on the review of past experiences.

- At the level of implementing project initiatives funded from EU sources, information activities should be performed to promote the fastest possible implementation of projects.

The economic and social position of the EU in the global arena is a determinant of coordinated actions of regional and national authorities. It is of particular importance for the Opolskie Voivodeship, as this region struggles with the negative outcomes of demographic processes. EU funds in 2014-2020 are the main tool of project initiatives that have a positive impact on macroeconomic economic indicators. However, this situation caused the emergence of new barriers that should be eliminated in order to achieve the best possible results in a short time in the payment of EU funds.

Author Contributions: Conceptualization, Ł.M., K.B., A.K. and M.S.-S.; data curation, Ł.M., K.B. and A.K.; formal analysis, Ł.M., K.B. and M.S.-S.; investigation, Ł.M. and M.S.-S.; methodology, Ł.M. and K.B.; project administration, A.K. and M.S.-S.; resources, Ł.M. and K.B.; validation, Ł.M. and A.K.; writing-original draft, Ł.M., K.B., A.K. and M.S.-S.; writing-review and editing, Ł.M., K.B. and A.K. All authors have read and agreed to the published version of the manuscript. 
Funding: This research received no external funding. The APC was funded by Opole University of Technology, Poland.

Data Availability Statement: Data supporting reported results can be found in the Marshal's Office of the Opolskie Voivodeship, Poland and on website: https://bdl.stat.gov.pl/BDL/start.

Conflicts of Interest: The authors declare no conflict of interest.

\section{Note}

1 Interpretation: If arrows point up, an investigated variable A precedes variable B for the relation expressed by A-B in the chart and if they point down, the circumstances are reversed; horizontal arrows directed right inform of processes that occur in-phase, i.e., courses of cycles that overlap, horizontal arrows directed left inform of "counter-phase", i.e., an overlap of peaks within a single process occurs, with instances representing valleys in the cycle in the second process.

\section{References}

Antonescu, Daniela. 2014. Regional Development Policy in Context of Europe 2020 Strategy. Procedia Economics and Finance 15: $1091-97$. [CrossRef]

Augustyniak, Hanna, Krzysztof Olszewski, and Krzysztof Gajewski. 2011. Informacja o cenach mieszkań i sytuacji na rynku nieruchomości mieszkaniowych i komercyjnych w Polsce 1 w II kwartale 2011 r. Available online: https://www.nbp.pl/ publikacje/rynek_nieruchomosci/ceny_mieszkan_06_2011.pdf (accessed on 24 September 2021).

Balemi, Nadia, Roland Füss, and Alois Weigand. 2021. COVID-19's impact on real estate markets: Review and outlook. Financial Markets and Portfolio Management, 1-19. [CrossRef]

Banaszewska, Monika, and Ivo Bischoff. 2021. Grants-in-aid and election outcomes in recipient jurisdictions: The impact of EU funds on mayoral elections in Poland. European Journal of Political Economy 68: 101993. [CrossRef]

Barbier, Edward B., Anil Markandya, and David W. Pearce. 1990. Environmental Sustainability and Cost-Benefit Analysis. Environment and Planning A 2: 1259-66. [CrossRef]

Barca, Fabrizio, Philip McCann, and Andrés Rodríguez-Pose. 2012. The case for Regional Development Intervention: Place-Based Versus Place-Natural Approaches. Journal of Regional Science 52: 134-52. [CrossRef]

Barska, Anetta, Janina Jędrzejczak-Gas, Joanna Wyrwa, and Krzysztof Kononowicz. 2020. Multidimensional Assessment of the Social Development of EU Countries in the Context of Implementing the Concept of Sustainable Development. Sustainability 12 : 7821. [CrossRef]

Batrancea, Ioan, Larissa Batrancea, Anca Nichita, Lucian Gaban, Ema Masca, Ioan-Dan Morar, Gheorghe Fatacean, and Andrei Moscviciov. 2019. An econometric approach on production, costs and profit in Romanian coal mining enterprises. Economic Research-Ekonomska Istraživanja 32: 1019-36. [CrossRef]

BDL. n.d. Statistics Office Poland. Available online: https://bdl.stat.gov.pl/BDL/start (accessed on 12 December 2020).

Bedrunka, Karina. 2015. Specjalizacje regionalne jako baza do podnoszenia poziomu innowacyjności w województwie opolskim (Regional specializations as a base for increasing the level of innovation in the Opolskie Voivodeship). In Efektywny transfer wiedzy $z$ nauki do przemystu w województwie opolskim. Edited by K. Malik and Ł. Dymek. Warszawa: Wydawnictwo Difin, pp. 70-79.

Bedrunka, Karina. 2020. Concepts of the Sustainable Development of the Region. In Sustainable production: Novel Trends in Energy, Environmental and Materials Systems. Edited by Grzegorz M. Królczyk, Małgorzata Wzorek, Anna Król, Orest Kochan, Jun Su and Janusz Kacprzyk. Berlin: Springer, pp. 11-18.

Bedrunka, Karina, and Łukasz Dymek. 2016. Pojeccie regionu i znaczenie jego rozwoju (The concept of the region and the importance of its development). In Ekonomia: Przewodnik dla studentów i doktorantów kierunków technicznych. Edited by Krzysztof Malik. Opole: Politechnika Opolska, pp. 101-10.

Bedrunka, Karina, and Krzysztof Malik. 2012. Zintegrowana efektywność polityki rozwoju regionalnego w kolejnym okresie programowania 2014-2020 (Integrated Efficiency and Effectiveness of the 2014-2020 Regional Development Policy Perspective). Hndel Wewnętrzny: Trendy i Wyzwania Zrównoważonego Rozwoju w XXI Wieku II: 7-18.

Bedrunka, Karina, and Krzysztof Malik, eds. 2014. Sustainable development as a criterion for eveluating the integrated implementation of the regional development policy. In Multi-Dimensional Effectivenessof Regional Development Policy. Implementation: Evaluation Scheme for the Opole Voivodeship. Warszawa: Polish Academy for Sciences Committee for Spatial Economy and Regional Planning, p. 168. ISBN 978-83-63563-73-8.

Bedrunka, Karina, Łukasz Mach, Anna Kuczuk, and Anna Bohdan. 2021. Identification and Analysis of Structural Fund Support Mitigating the Effects of the COVID-19 Pandemic in the EU-A Case Study of Health Unit Funding. Energies 14: 4976. [CrossRef]

Biela, Adam. 2001. Metodologia wyceny kapitału ludzkiego w kontekście koncepcji zrównoważonego rozwoju. In Ekonomia a rozwój zrównoważony, tom 1-Teoria i Kształcenie. Edited by Franciszek Piontek. Białystok: Wydawnictwo Ekonomia i Środowisko, pp. 207-28.

Boin, Arjen, Martin Lodge, and Marte Luesink. 2020. Learning from the COVID-19 crisis: An initial analysis of national responses. Policy Design and Practice 3: 189-204. [CrossRef] 
Borys, Tadeusz. 2001. Jakość życia a zrównoważony rozwój. Relacja i pomiar. In Ekonomia a rozwój zrównoważony. Teoria i kształcenie. Edited by Franciszek Piontek. Białystok: Wydawnictwo Ekonomia i Środowisko, chp. 1. p. 81.

Borys, Tadeusz. 2005. Wskaźniki zrównoważonego rozwoju. Białystok: Wydawnictwo Ekonomia i Środowisko.

Cardenete, Manuel Alejandro, and M. Carmen Delgado. 2015. A simulation of impact of withdrawal European funds on Andalusian economy using a dynamic CGE model: 2014-20. Economic Modelling 45: 83-92. [CrossRef]

Chądzyński, Jacek, Aleksandra Nowakowska, and Zbigniew Przygodzki. 2012. Region i jego rozwój w warunkach globalizacji (The Region and Its Development in the Conditions of Globalization). Warszawa: Wydawnictwo Fachowe, CeDEWu.pl, pp. 1-252.

Chłoń-Domińczak, Agnieszka, Irena E. Kotowska, Jolanta Kurkiewicz, Marcin Stonawski, and Anita Abramowska-Kmon. 2014. Population Ageing in Europe: Facts, Implications and Policies. Brussels: Outcomes of EU-Funded Research. European CommisionResearch and Innovation. European Union, pp. 1-77. [CrossRef]

Crescenzi, Riccardo, Marco Di Cataldo, and Mara Giua. 2019. LSE “Europe in Question”. Discussion Paper Series It's Not about the Money! EU FUNDS, Local Opportunities, and the Brexit Vote. 2019, LEQS Paper No. 149/2019. Available online: http: //www.lse.ac.uk/european-institute/research/leqs-discussion-paper-series (accessed on 24 September 2021).

Croom, Brandon, Sean Kennedy, Sandesh Ojha, and Justin Sparks. 2020. Analysis of the Commercial Real Estate Market in a post COVID-19 World. SMU Data Science Review 3: 5. Available online: https://scholar.smu.edu/datasciencereview/vol3/iss3/5 (accessed on 4 October 2021).

Cunico, Giovanni, Eirini Aivazidou, and Edoardo Mollona. 2021. Beyond financial proxies in Cohesion Policy inputs' monitoring: A system dynamics approach. Evaluation and Program Planning 89: 101964. [CrossRef]

Czaja, Stanisław. 1992. Entropijno-energetyczna analiza procesów gospodarczych. Kierunki rozwoju analizy energetycznej (The Entropic and Energetic Analysis of Economic Processes. The Development Directions of the Energetic Analysis). Ekonomia $i$ Środowisko 2: 9-20.

De Toro, Pasquale, Francesca Nocca, and Francesca Buglione. 2021. Real Estate Market Responses to the COVID-19 Crisis: Which Prospects for the Metropolitan Area of Naples (Italy)? Urban Science 5: 23. [CrossRef]

Dell'Ariccia, Giovanni, Pau Rabanal, Christopher Crowe, and Deniz Igan. 2021. Cover Staff Discussion Notes Policies for Macrofinancial Stability: Options to Deal with Real Estate Booms. Journal of Financial Stability 2011: 2-33.

Di Mauro, Filippo, Stephane Dees, and Warwick J. McKibbin. 2010. Regionalism and Economic Interdependence. Cambridge: Cambridge University Press, pp. 1-182.

Dziedzic, Sylwia, Leszek Woźniak, and Maciej Chrzanowski. 2015. Inteligentne specjalizacje jako droga dla zrównoważonego rozwoju (Smart specializations as a path for sustainable development). In Zrównoważony rozwój organizacji-odpowiedzialność środowiskowa. Edited by Tadeusz Borys, Bartosz Bartniczak and Michał Ptak. Wrocław: Wydawnictwo Naukowe Uniwersytetu Ekonomicznego, vol. 377, pp. 267-79.

El Serafy, Salah. 1991. The environment as capital. In Ecological Economics: The Science and Management of Sustainability. Edited by Robert Costanza. New York: Columbia University Press, pp. 168-75.

European Commission. 2021. Available online: https://ec.europa.eu/eurostat/web/products-eurostat-news/-/ddn-20210303-1 (accessed on 12 December 2020).

European Commission. 2010a. Commission Staff Working Document Document accompanying the Commission Communication on Regional Policy Contributing to Smart Growth in Europe 2020. Brussels, Belgium. Available online: https: / / ec.europa.eu/ regional_policy/sources/docoffic/official/communic/smart_growth/annex_comm2010_553.pdf (accessed on 10 January 2021).

European Commission. 2010b. Europe 2020 Communination from the Commission, Europe 2020. A Strategy for Smart, Sustainable and Inclusive Growth. Brussels, Belgium. Available online: https:/ / eur-lex.europa.eu/legal-content/EN/TXT/PDF/?uri=CELEX: 52010DC2020\&from=PL (accessed on 10 January 2021).

Foray, Dominique, Paul A. David, and Bronwyn H. Hall. 2011. Smart specialization-From academic idea to political instrument, the surprising career of a concept and the difficulties involved in its implementation. In Working Paper Series, Management of Technology and Entrepreneurship Institute. Lausanne: College of Management of Technology, pp. 1-16.

Foray, Dominique, and Xabier Goenaga. 2013. The Goals of Smart Specialisation. In JRC Scientific and Policy Reports. S3 Policy Brief Series. Luxembourg: Publications Office of the European Union, vol. 1, pp. 1-14.

Foray, Dominique, Kevin Morgan, and Slavo Radosevic. 2018. The Role of Smart Specialisation in the EU Research and Innovation Policy Landscape. European Commission-Regional and Urban Policy 1-20. Available online: https:/ / ec.europa.eu (accessed on 10 January 2021).

Iuga, Iulia Cristina, and Anastasia Mihalciuc. 2020. Major Crises of the XXIst Century and Impact on Economic Growth. Sustainability 12: 9373. [CrossRef]

JLL Research \& Strategy. 2020. COVID-19: Global Real Estate Implications, Paper II. Hillsborough: Global Research, April 20. Available online: https:/ / www.jll.it/it/tendenze-e-ricerca/research/covid-19-global-real-estate-implications (accessed on 4 October 2021).

Kangas, Riikka, and Timo Aarrevaara. 2020. Higher Education Institutions as Knowledge Brokers in Smart Specialisation. Sustainability 12: 3044. [CrossRef]

Klasik, Andrzej. 2006. Przedsiębiorczość i konkurencyjność a rozwój regionalny—Wprowadzenie (Entrepreneurship and competitiveness versus regional development-Introduction). In Przedsiębiorczość i konkurencyjność a rozwój regionalny. Edited by A. Klasik. Katowice: Prace Naukowe, Akademia Ekonomiczna w Katowicach, pp. 15-58.

Kudłacz, Tadeusz. 1999. Programowanie Rozwoju Regionalnego (Programming of Regional Development). Warszawa: PWN, pp. 1-180. 
Lafuente, Juan Ángel, Amparo Marco, Mercedes Monfort, and Javier Ordóñez. 2020. Social Exclusion and Convergence in the EU: An Assessment of the Europe 2020 Strategy. Sustainability 12: 1843. [CrossRef]

Mach, Łukasz. 2021. Analiza Zmienności czasowo-częstotliwoścowej rynku budonictwa mieszkaniowego. Warszawa: SGH w Warszawie.

Malik, Krzysztof. 2011. Ewaluacja polityki rozwoju regionu. Metody, konteksty i wymiary rozwoju zrównoważonego (Evaluation of regional development policy: Methods, contexts and dimensions of sustainable development). Studia Komitet Przestrzennego Zagospodarowania Kraju PAN 135: 3-187.

Mayer-Stamer, Jörg. 2016. Systemic Competitiveness and Local Economic Development. In Large Systemic Change: Theories, Modelling and Practices. Edited by Shamim Bodhanya. Duisburg: Meso Partner, chp. 11.

Mazur-Wierzbicka, Ewa. 2015. Wzrost sprzyjający włączeniu społecznemu jako wyzwanie dla Polski w świetle Strategii Europa 2020 (Inclusive growth as a challenge for Poland in the light of the Europe 2020 Strategy). Studia Ekonomiczne, Zeszyty Naukowe Uniwersytetu Ekonomicznego 213: 69-184.

Nowakowska, Aleksandra. 2015. Budowanie inteligentnych specjalizacji-Doświadczenia i dylematy polskich regionów (Building smart specializations-Experiences and dilemmas of Polish regions). Studia Prawno-Ekonomiczne XCVII: 325-40.

OECD. n.d. Regional Development Policy. Source Details. Available online: http:/ / www.oecd.org/regional/regionaldevelopment.htm (accessed on 6 November 2020).

Ponsiglione, Cristina, Ivana Quinto, and Giuseppe Zollo. 2018. Regional Innovation Systems as Complex Adaptive Systems: The Case of Lagging European Regions. Sustainability 10: 2862. [CrossRef]

Radulescu, Magdalena, Aleksandra Fedajev, Crenguta Ileana Sinisi, Constanta Popescu, and Silvia Elena Iacob. 2018. Europe 2020 Implementation as Driver of Economic Performance and Competitiveness. Panel Analysis of CEE Countries. Sustainability 10: 566. [CrossRef]

Schmidhuber, J., and B. Qiao. 2020. Comparing Crises: Great Lockdown versus Great Recession. Rome, Italy: FAO.

Širá, Elena, Roman Vavrek, Ivana Kravčáková Vozárová, and Rastislav Kotulič. 2020. Knowledge Economy Indicators and Their Impact on the Sustainable Competitiveness of the EU Countries. Sustainability 12: 4172. [CrossRef]

Stawasz, D. 2004. Gospodarka regionalna-Teoria i praktyka (Regional economy—theory and practice). In Ekonomiczne i organizacyjne uwarunkowania rozwoju regionu-teoria i praktyka. Edited by D. Stawasz. Łódź: Wydawnictwo Uniwersytetu Łódzkiego.

Szlachta, Jacek. 1996. Główne problemy polityki rozwoju regionalnego Polski na przełomie XX i XXI wieku (Main problems of the Polish regional development policy at the turn of the 20th and 21st centuries). In Strategiczne wyzwania dla polityki rozwoju regionalnego Polski. Edited by Ryszard Broszkiewicz. Warszawa: Friedrich-Ebert-Stiftung-Przedstawicielstwo w Polsce.

Sztando, Andrzej. 1998. Oddziaływanie samorządu lokalnego na rozwój lokalny w świetle ewolucji modeli ustrojowych gmin (The impact of local government on local development in the light of the evolution of system models in communes). Samorzad Terytorialny 11: 12-29.

Tomer, John F. 1987. Organizational Capital: The Path to Higher Productivity and Well-Being Praeger. Journal of Economic Behavior and Organization 11: 453-55.

Zalewska, Mariola E., and Piotr Świetlikowski. 2017. Ocena szans realizacji głównych celów Strategii Europa 2020 w krajach grupy wyszehradzkiej (Assessment of the chances of achieving the main goals of the Europe 2020 Strategy in the countries of the Visegrad group). Zeszyty Naukowe Politechniki Ślaskiej. Seria: Organizacja i Zarzadzanie 104: 367-78.

Zarzą Województwa Opolskiego. 2014. Regionalna Straregia Innowacji Województwa Opolskiego do 2020 roku. Available online: https:/ / rpo.opolskie.pl/wp-content/uploads/Regionalna_Strategia_Innowacji_Wojew\%C3\%B3dztwa_Opolskiego_do_ roku_2020.pdf (accessed on 12 November 2020).

Zhang, Dayong, Jing Cai, Jia Liu, and Ali M. Kutan. 2018. Real estate investments and financial stability: Evidence from regional commercial banks in China. The European Journal of Finance 24: 1388-408. [CrossRef] 